\title{
Understanding the El Niño Costero of 2017: The Definition Problem and Challenges of Climate Forecasting and Disaster Responses
}

\author{
Ivan J. Ramírez ${ }^{1,2,3} \cdot$ Fernando Briones $^{2}$
}

Published online: 13 December 2017

(C) The Author(s) 2017. This article is an open access publication

\begin{abstract}
This preliminary study examines the definition problem and challenges of climate forecasting and disaster responses associated with the El Niño costero (coastal) of 2017, which developed rapidly with no warning and had catastrophic effects in Peru. Such a localized El Niño was not documented since 1925. An initial review suggests that in addition to the characteristics of the event (surprise), government responses may have been inadequate (as media reported) because of conflicting forecast reports (U.S. and Peru), which provoked a hydrometeorological debate and stifled decision making. Partly to blame was the El Niño definition problem, which can cause uncertainty and affect perception of risk, depending on which region of the equatorial Pacific one uses to identify an event. Responses were further complicated by the fact that some regions within Peru were experiencing drought prior to the El Niño costero's onset and impacts from the El Niño 2015-2016 were less than expected. Furthermore, a new government was in place, which may have hindered action. Thus, El Niño costero provides lessons to heed, not only with respect to the forecast information, but also with reference to the context of the forecast and disaster setting, which can influence disaster responses to hydrometeorological threats.
\end{abstract}

Ivan J. Ramírez

ivan.cxa@gmail.com

1 Department of Anthropology, Colorado State University, Fort Collins, CO 80523, USA

2 Consortium for Capacity Building/INSTAAR, University of Colorado, Boulder, CO 80309, USA

3 Graduate Program in Public Health, Colorado State University, Fort Collins, CO 80523, USA
Keywords Disaster risk reduction · Ecuador · El Niño costero $\cdot$ El Niño forecast $\cdot$ El Niño-Southern Oscillation $\cdot$ Peru $\cdot$ Teleconnections

This study is a preliminary examination of the impacts and societal responses associated with the recent El Niño costero (coastal), which came as a surprise to the scientific community, governments, and populations in northwest South America in terms of its rapid development and localized impacts. Our research builds on previous El Niño-related work in the region (Ramírez et al. 2013; Ramírez and Grady 2016) and is part of a broader project that seeks to understand the strengths of and challenges to government responses to hydrometeorological threats in an El Niño-sensitive region. ${ }^{1}$ The goal is to identify lessons for disaster risk reduction (DRR) and long-term development planning that can be used to build societal resilience and thus increase El Niño readiness at national and subnational-levels. In this short article, we highlight the El Niño definition problem and challenges of climate forecasting and disaster responses, which can cause debate and hinder preventive actions, thereby reducing capacities to cope and respond to hydrometeorological threats.

The northwestern region of South America is a climatesensitive area, prone to quasi-periodic hydrometeorological anomalies associated with El Niño, the warm extreme of El Niño-Southern Oscillation (ENSO). The El Niño costero that developed in mid-January and subsided by May 2017 differs from the El Niño basin-wide phenomenon because it was spatially confined along the coasts of Peru and Ecuador (Takahashi 2017), as opposed to the El Niño-related expansion of warm waters coming from the western

\footnotetext{
${ }^{1}$ http://elninoreadynations.com/.
} 
and central equatorial Pacific. Preliminary scientific literature in Peru suggests El Niño costero is not a new type, but rather it is a different kind of El Niño such as the one documented in 1925 (Takahashi and Martínez 2017), which Peruvians remember as a disastrous event of great magnitude on their northern coast (Murphy 1926; Cordova Aguilar 1996). El Niño costero's evolution and impacts are still under investigation. Regardless of how the coastal El Niño differs from the basin-wide El Niño, the impacts of the 2017 El Niño costero on ecosystems and societies in Peru were significant and similar with other extraordinary El Niños, such as the 1982-1983 and 1997-1998 episodes, both of which were considered the strongest events of the twentieth century.

Preliminary governmental assessments of the El Niño costero damages documented the devastation experienced by Peruvians in terms of loss of lives and infrastructure across the country. Economic losses due to El Niño-related torrential rains were estimated at USD 3.1 billion, as of 28 March 2017 (Leon and Kraul 2017). The number of people affected was close to 1.1 million, as of 12 May 2017 (INDECI 2017). El Niño's effects were distributed unevenly across Peru's geographic regions and the most severe impacts (based on percentage of people affected in Peru) were reported in cities in the northern coastal departments of Piura (32\%), Lambayeque (16\%), and La Libertad (5\%), as well as in the central coastal department, Lima (5\%), where the capital is located (PAHO 2017). Of the population impacted, approximately 284,790 children (24\%) were affected, including 90 deaths (UNICEF 2017). An array of infectious disease epidemics also have been reported, including dengue, chikungunya, zika, and leptospirosis, which indicates an increase in incidence in 2017 compared to the previous year (PAHO 2017).

El Niño researchers in the Americas, including those in the United States and Peru, did not see the coastal event developing despite a basin-wide monitoring system across the Pacific. Thus, government agencies, socioeconomic sectors, public health officials, and citizens alike were not forewarned of its potential climate and environmental-related hazards, which include droughts, floods, flash floods, landslides, and fires, as well as storm surges, and sea-level changes. So why did the monitoring system not identify the threat?

One potential reason is the inherent problem of the El Niño definition that is widely used and critical for the ENSO Alert system of the National Oceanic and Atmospheric Administration (NOAA 2017a). The development of the ENSO cycle is closely monitored in a system (NOAA's Climate Prediction Center ${ }^{2}$ ) that allows scientists

\footnotetext{
2 http://www.cpc.ncep.noaa.gov/products/precip/CWlink/MJO/enso. shtml.
}

to observe environmental changes across the Pacific and issue watches and warnings if an El Niño or La Niña emerges (NOAA 2017c). According to this ENSO Alert system, El Niños and La Niñas are positive and negative sea surface temperature (SST) anomalies, respectively, that exceed a $\pm 0.5^{\circ} \mathrm{C}$ threshold for five consecutive 3-month periods. The region of focus is the central and eastern equatorial Pacific known as Niño $3.4 .^{3}$ This region is the basis of the Oceanic Niño Index (ONI) that guides the alert system by using SST along with other climate parameters, such as winds, outgoing long wave radiation, and atmospheric pressure changes (the Southern Oscillation Index).

Although the Niño 3.4 region is important for prediction and monitoring, particularly for basin-wide El Niños, it is not always the best area for observing other varieties of El Niño that develop or the ecological impacts that may concentrate along the coasts of northern Peru and southern Ecuador. For example, according to the ONI index, the ocean-atmosphere conditions during the costero period were in transition from La Niña (5-months, August-December 2016) to ENSO's neutral phase. Hence, NOAA's ENSO Diagnostic discussion reports did not acknowledge the El Niño phenomenon that was rapidly evolving along the Peruvian and Ecuadorian coasts, although there is mention of an SST anomaly of $1.5^{\circ} \mathrm{C}$ in the Niño $1+2$ region in the February report (NOAA 2017b).

Given the geographic proximity of the equatorial and coastal upwelling regions to Peru's coast, and its environmental and economic relevance (for example, fisheries), Peruvians also monitor SST conditions in the Niño $1+2$ region and have developed their own index called the "Indice Costero El Niño" (Coastal El Niño Index, ICEN) based on Niño $1+2$ SST (Takahashi et al. 2014). The ICEN index defines warm and cold events on an asymmetric scale that adjusts for threshold differences estimated for El Niños and La Niñas. For example, El Niños are categorized as SST anomalies $>0.4{ }^{\circ} \mathrm{C}$ for three consecutive months; La Niñas are categorized as anomalies $<$ $1.0{ }^{\circ} \mathrm{C}$ for three consecutive months. The ICEN Index also provides criteria for qualifying the strength of an extreme phase along a spectrum from weak to strong. Although the ICEN index was able to capture the El Niño costero period, the index neither accurately characterized its true magnitude (that is, the ICEN index qualified the event as weak compared to strong anomalies monitored closer to the coast) nor identified the El Niño costero soon enough to allow lead time for an early warning. Late recognition could be due to a definition problem, one that is inadequate to recognize the coastal type event, or perhaps El Niño costero was simply a climate surprise.

\footnotetext{
${ }^{3}$ https://www.ncdc.noaa.gov/teleconnections/enso/indicators/sst.php.
} 
Complicating the monitoring and definition situation further is the fact that many countries, including Peru and Ecuador, rely on the NOAA ENSO alert system and forecast models that estimate the probability of El Niño occurrence. The system produces monthly ENSO discussions, which are linked to other organization discussions (for example, World Meteorological Organization), which are posted online and circulated worldwide. They provide an important climate service, but may also be a source of confusion when events other than basin-wide El Niños emerge. For Peru and neighboring Andean countries, the NOAA reports provide critical information that regional scientists compare (that is, Niño 3.4 region vs. Niño $1+2$ region) using their own expert judgement to assess the forecast summaries. According to Peru's Multisectoral Committee for the Study of El Niño (ENFEN 2016), forecasts as of 9 December 2016 for both regions predicted that SST conditions were strongly leaning towards ENSOneutral until the end of southern hemisphere summer (northern hemisphere winter), although ENFEN also noted that along the Peruvian coast SSTs were subtly above average, but within neutral range. By 16 January 2017, the Eastern Pacific assessment (Niño $1+2$ ) indicated a $30 \%$ chance that a weak El Niño would develop, but chances of ENSO-neutral were even greater, $66 \%$, which informed the forecasters' consensus that ENSO-neutral was most appropriate, despite noting persistent coastal SST anomalies (ENFEN 2017a). In terms of NOAA, it was not until 9 February 2017, now in the midst of an evolving El Niño costero that forecasters reported anomalous conditions in the far eastern Pacific (IRI 2017a; NOAA 2017b), albeit, while also reporting that ENSO-neutral would continue through northern hemisphere spring $(60 \%)$, and predicting an El Niño for the northern hemisphere fall (50\%). By March, the International Research Institute for Climate and Society (IRI 2017b) reported a coastal El Niño in Peru and Ecuador, although the conclusion, like the previous month's discussion, was that ENSO-neutral was present in the Niño 3.4 region and would persist through May.

On 24 January and 2 February, ENFEN (2017b, 2017c) issued an El Niño costero watch based on SST observations using the ICEN index, coastal conditions (rapid increase of SST), including biological responses (decreased primary productivity) and inland conditions (intense rains, above average river levels). It was only a few days later (6 February) that news reports ${ }^{4}$ would highlight loss of life (25 dead), property (15 buildings), infrastructure (14 bridges and $42 \mathrm{~km}$ of road), and population affected $(72,000)$, due to intense rains in northern Peru. Also

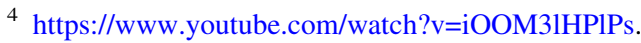

reported was the lack of preparedness by the government to address such rain-related disasters; critiques that were echoed by media outlets in regards to responses before (no preparations) and after the first rains (Collyns and Watts 2017), including not providing enough resources to regions affected most (Sarmiento 2017). The event exposed Peru's social vulnerabilities and the ineffectiveness of short-term responses, such as maintenance fixes of drainages and canals, versus long-term planning, for example in urbanization policy (McRae 2017).

Although the definition problem sets the stage for a hydrometeorological debate and uncertainty, which includes how to interpret the various sources of El Niño information to determine if an El Niño is happening, it is also part and parcel of a broader challenge associated with climate forecasting and disaster responses. As Glantz has noted, there are a number of factors that influence the responses of governments and other stakeholders including perception of risk, "the credibility of forecasters," "the ability of a government to engage in disaster preparedness," and "the ability of a government to communicate to its citizens the risk involved" (1994, p. 7). A preliminary assessment of the El Niño costero suggests that perception of risk could have been muddled, given conflicting forecasts, including those from the traditionally reliable international sources. The country was also experiencing severe drought and, therefore, rains were particularly welcomed by anxious farmers (Collyns and Watts 2017). This factor suggests that risk is relative or even viewed in light of other risks as a tradeoff. Perceived risk (and subsequent inaction or inadequate government disaster responses) may have been influenced by the fact that impacts from the 2015-2016 El Niño turned out to be less than expected and feared in Peru, which in turn may also have diminished the credibility of subsequent climate information. Also a relatively new government was in office. Just six months in power, the young administration was still getting organized at different decision-making levels, and thus its ability to act quickly and decisively may have been limited. Taken together with the major characteristic of the event-surprise-these factors may have contributed to a context of compounding uncertainty, which stifled national responses and hindered decision making and adequate action. The case of the El Niño costero should be viewed as a lesson for governments and forecasters to heed attention to not only the climate information generated by forecasts, but also the context of the forecast and disaster setting, which is equally important and can influence societal responses to hydrometeorological threats. It is important for disaster preparedness to realize that rarely seen climate surprises have a probability of occurrence, although their infrequent appearance means that they are seldom if ever given serious consideration. 
Acknowledgements This study was made possible through the support provided by the Office of U.S. Foreign Disaster Assistance, Bureau for Democracy, Conflict and Humanitarian Assistance, U.S. Agency for International Development. The opinions expressed in this publication are those of the authors and do not necessarily reflect views of the U.S. Agency for International Development. This manuscript was improved by comments and suggestions by Dr. Michael H. Glantz and reviewers.

Open Access This article is distributed under the terms of the Creative Commons Attribution 4.0 International License (http://crea tivecommons.org/licenses/by/4.0/), which permits unrestricted use, distribution, and reproduction in any medium, provided you give appropriate credit to the original author(s) and the source, provide a link to the Creative Commons license, and indicate if changes were made.

\section{References}

Collyns, D., and J. Watts. 2017. Peru floods kill 67 and spark criticism of country's climate change preparedness. The Guardian, 17 March 2017. https://www.theguardian.com/world/2017/mar/17/ peru-floods-ocean-climate-change. Accessed 6 Jun 2017 (in Spanish).

Cordova Aguilar, H. 1996. Piura. Geospacios 9. Universidad de la Serena, Peru (in Spanish).

ENFEN (Multisectoral Committee for the Study of El Niño). 2016. Official communication (Comunicado oficial), ENFEN No. 16-2016. 9 December 2016 (in Spanish).

ENFEN (Multisectoral Committee for the Study of El Niño). 2017a. Official communication (Comunicado oficial), ENFEN No. 1-2017. 16 January 2017 (in Spanish).

ENFEN (Multisectoral Committee for the Study of El Niño). 2017b. Official communication (Comunicado oficial), ENFEN No. 2-2017. 24 January 2017 (in Spanish).

ENFEN (Multisectoral Committee for the Study of El Niño). 2017c. Official communication (Comunicado oficial), ENFEN No. 2-2017. 2 February 2017 (in Spanish).

Glantz, M.H. 1994. Introduction. In Usable science: Food security, early warning and El Niño, ed. M.H. Glantz, 3-11. Proceedings of the workshop on ENSO/FEWS, 25-28 October 1993, Budapest, Hungary. Boulder: National Center for Atmospheric Research. http://www.ilankelman.org/glantz/Glantz1993Useable Science1.pdf. Accessed 1 Sept 2017.

INDECI (Instituto Nacional de Defensa Civil/Civil Defense). 2017. 1. Reporte de situacion lluvias. 2. Reporte de informacion del Ministerio de Salud consecuencia del Niño Costero, 12 May. http://www.indeci.gob.pe/objetos/noticias/NTY=/NTE1Mw==/ fil20170512180616.pdf. Accessed 14 Jul 2017 (in Spanish).

IRI (International Research Institute for Climate and Society). 2017a. ENSO forecast. IRI Technical ENSO Update. 16 February 2017. https://iri.columbia.edu/our-expertise/climate/forecasts/enso/2017February-quick-look/?enso_tab=enso-iri_update. Accessed 1 Sept 2017.

IRI (International Research Institute for Climate and Society). 2017b. ENSO forecast. IRI Technical ENSO Update. 16 March 2017. https://iri.columbia.edu/our-expertise/climate/forecasts/enso/2017March-quick-look/?enso_tab=enso-iri_update. Accessed 1 Sept 2017.
Leon, A., and C. Kraul. 2017. Peru's brutal season of floods leaves 94 dead, 700,000 homeless. The Los Angeles Times, 28 March 2017. http://www.latimes.com/world/mexico-americas/la-fg-peru-floods20170328-story.html. Accessed 6 Jun 2017.

McRae, D. 2017. Weathering the storm. North American Congress in Latin America (NACLA). https://nacla.org/news/2017/04/20/ weathering-storm. Accessed 6 Jun 2017.

Murphy, R.C. 1926. Oceanic and climatic phenomena along the west coast of South America during 1925. Geographical Review 16: $26-54$.

NOAA (National Oceanic and Atmospheric Administration). 2017a. Cold and warm episodes by season. http://origin.cpc.ncep.noaa. gov/products/analysis_monitoring/ensostuff/ONI_v5.php. Accessed 17 Aug 2017.

NOAA (National Oceanic and Atmospheric Administration). 2017b. ENSO diagnostic discussion. 9 February 2017. http://origin.cpc. ncep.noaa.gov/products/analysis_monitoring/enso_disc_feb2017/ ensodisc.shtml. Accessed 17 Aug 2017.

NOAA (National Oceanic and Atmospheric Administration). 2017c. ENSO diagnostic discussion. 12 October 2017. http://www.cpc. ncep.noaa.gov/products/analysis_monitoring/enso_advisory/enso disc.shtml. Accessed 12 Oct 2017.

PAHO (Pan American Health Organization). 2017. Rains and floods in Peru. Situation report (Lluvia e inundaciones en Peru. Reporte de situation) No. 13, 23 April 2017. https://reliefweb.int/sites/ reliefweb.int/files/resources/Informe_Situacion_13-2017_Peru_ Inundaciones_23_abril\%5B1\%5D.pdf. Accessed 6 Jun 2017 (in Spanish).

Ramírez, I.J., and S. Grady. 2016. El Niño, climate and cholera associations in Piura, Peru, 1991-2001: A wavelet analysis. EcoHealth 13: 83-99.

Ramírez, I.J., S.C. Grady, and M.H. Glantz. 2013. Reexamining El Niño and cholera in Peru: A climate affairs approach. Weather, Climate and Society 5: 148-161.

Sarmiento, M. 2017. Cual fue el presupuesto de cada region y cuanto utilizaron para prevenir "El Niño costero"? https://redaccion. lamula.pe/2017/03/21/cual-fue-el-presupuesto-de-cada-region-ycuanto-utilizaron-para-prevenir-el-nino-costero-u/lumasap/. Accessed 6 Sept 2017 (in Spanish).

Takahashi, K. 2017. The El Niño phenomenon: Global vs coastal (Fenómeno El Niño: Global vs "Costero"). Generacion de informacion y monitoreo del Fenómeno El Niño-Boletin Tecnico. 4(4). Instituto Geofísico del Perú. Ministerio del Ambiente, Perú (in Spanish).

Takahashi, K., and A.G. Martínez. 2017. The very strong coastal El Niño in 1925 in the far-eastern Pacific. Climate Dynamics. https://doi.org/10.1007/s00382-017-3702-1.

Takahashi, K., K. Mosquera, and J. Reupo. 2014. The El Niño Costero index: History and operationalization (El Indice Costero El Niño (ICEN): historia y actualizacion). Boletin Tecnico (IGP), 1, No. 2, February 2014. http://www.met.igp.gob.pe/ publicaciones/2014/ElNino_v2_27_03_2014_7.pdf. Accessed 6 Jun 2017 (in Spanish).

UNICEF (United Nations Children's Fund). 2017. Peru's humanitarian situation report No. 2, 27 March 2017. https://reliefweb.int/ sites/reliefweb.int/files/resources/UNICEF\%20Peru\%20Humani tarian\%20Situation\%20Report\%20\%23\%202\%20-\%2027\%20 March\%202017.pdf. Accessed 26 Jun 2017. 